\title{
Study of emulsifying properties of soluble proteins obtained from defatted rice bran concentrate
}

\author{
Carla Bonifacino ${ }^{1}$, Gonzalo Palazolo², Luis Panizzolo ${ }^{3}$, and Cecilia Abirached ${ }^{3}$ \\ ${ }^{1}$ Universidad de la República Facultad de Química \\ ${ }^{2}$ Universidad Nacional de Quilmes \\ ${ }^{3}$ Universidad de la Republica Facultad de Quimica
}

February 28, 2021

\begin{abstract}
Rice (Oryza sativa) is one of the most frequently produced cereals in the world. Rice bran (RB) is obtained as a by-product in the rice milling process. A part of the RB is used for oil extraction, obtaining defatted rice bran (DRB) as a second byproduct. The aim of this work was to analyze the emulsifying properties of soluble proteins fraction present in defatted rice bran concentrate (DRBC) in acidic and neutral conditions. Fine emulsions (prepared by high-speed and ultrasound homogenization) stabilized with soluble proteins obtained from DRBC showed a mean particle size lower than coarse emulsions (prepared by only high-speed homogenization) and a significantly lower degree of overall destabilization. Coarse emulsions showed sigmoidal destabilization profiles at $\mathrm{pH} 4.5$ and 7.0, related to the existence of two populations with different particle sizes. In fine emulsions, both $\mathrm{pH}$ provided lower particle sizes and greater stability. After $24 \mathrm{~h}$ of quiescent storage, the coarse emulsions showed an increase of particle size that was not observed in fine emulsions. Both types of emulsions showed a Newtoniantype behavior. Fine emulsions showed higher viscosity values and higher lightness than coarse emulsions, consistent with the reduction of particle size and increase in the number of particles. The soluble proteins obtained from a waste of the rice industry can be used to obtain stable fine oil-in-water emulsions in acidic and neutral conditions. This result is of interest since it could be used as a food ingredient, increasing the added value of this important by-product.
\end{abstract}

\section{Hosted file}

Main Document.pdf available at https://authorea.com/users/398656/articles/511293-study-ofemulsifying-properties-of-soluble-proteins-obtained-from-defatted-rice-bran-concentrate

\section{Hosted file}

Fig. 1.pdf available at https://authorea.com/users/398656/articles/511293-study-ofemulsifying-properties-of-soluble-proteins-obtained-from-defatted-rice-bran-concentrate

\section{Hosted file}

Fig. 2.pdf available at https://authorea.com/users/398656/articles/511293-study-ofemulsifying-properties-of-soluble-proteins-obtained-from-defatted-rice-bran-concentrate

\section{Hosted file}

Fig. 3.pdf available at https://authorea.com/users/398656/articles/511293-study-ofemulsifying-properties-of-soluble-proteins-obtained-from-defatted-rice-bran-concentrate

\section{Hosted file}


Fig. 4.pdf available at https://authorea.com/users/398656/articles/511293-study-ofemulsifying-properties-of-soluble-proteins-obtained-from-defatted-rice-bran-concentrate Hosted file

Fig. 5.pdf available at https://authorea.com/users/398656/articles/511293-study-ofemulsifying-properties-of-soluble-proteins-obtained-from-defatted-rice-bran-concentrate 